\title{
Erratum
}

\section{Trade-offs and Veto Players: Reforming Pensions in France and Italy}

David Natali and Martin Rhodes

French Politics (2004) 2, 245. doi:10.1057/palgrave.fp.8200060

Correction to: French Politics (2004) 2, 1-23. doi:10.1057/palgrave.fp.8200048

In the above paper incorrect keywords were published and the spelling of a referee's name within the reference section was incorrect. The correct keywords and reference appear below:

France; Italy; pensions; policy-making; concertation; trade unions

Culpepper, P. (2002) 'Powering puzzling and 'pacting': the informational logic of negotiated reforms', Journal of European Public Policy 9(5): 774-790. 